\title{
Comparison of two dot immunoassays for diagnosis of dengue infection.
}

\author{
Agus Sjahrurachman, Betty Emawati, Fera Ibrahim, Mardiastuti, Tjahjani Mirawati Sudiro, Pratiwi Sudarmono
}

\begin{abstract}
Abstrak
Diagnosis definitif infeksi virus dengue memerlukan konfirmasi laboratorium, karena diagnosis tersebut sukar sekali ditegakkan bila hanya berdasarkan gejala dan tanda klinis. Oleh sebab itu pemeriksaan laboratorium berperan penting dalam pengelolaan kasus dan pemberantasan penyakitnya. Mengingat kebanyakan kasus infeksi dengue terdapat di negara berkembang dimana sarana laboratorium banyak yang tidak memadai, diperlukan cara pemeriksaan laboratorium yang cepat dan sederhana. Dalam makalah ini dilaporkan perbandingan uji dot imunoesei yang kami kembangkan dengan salah satu kit dot imunoesei komersil dengan pembanding uji hambatan hemaglutinasi. Hasilnya menunjukkan bahwa dot imunoesei yang kami kembangkan mempunyai sensitifitas dan spesifisitas tinggi.
\end{abstract}

\begin{abstract}
Definite diagnosis of dengue infection plays an important role of case management and disease control. Unfortunately, majority of the infected cases can not be diagnosed solely on the basis of clinical signs and symptoms. Laboratory investigations are required. Since dengue distribution mostly present in developing countries, appropriate laboratory diagnosis would be a rapid and simple one. Here, we report a preliminary assessment of a dot immunoassay employing biotinylated-dengue antigens for detection of IgM-antidengue antibodies which is simple in term of methodology and rapid in term of the test result. This study was done by comparing out method with standard H.I test and commercially available dot immunoassay. The results indicate that the dot immunoassay employing biotinylated-dengue (BDIA) is sensitive and specific for diagnosis of dengue infection.
\end{abstract}

Keywords: qualitative immunoassay, diagnosis, dengue infection

Dengue haemorrhagic fever is one among the most important emerging infectious disease ${ }^{1,2}$ showing expansion of its geographical distribution. ${ }^{3}$ It has been estimated that more than two and half billion of people are at risk of infection. ${ }^{1,2}$ It is estimated that there are annually 20 million cases of dengue infections all over the world resulting in around 24.000 deaths. $^{2}$ On the other hand, it well known that dengue infection may induce a wide variety of clinical entity from mild undifferentiated fever to a severe, often fatal dengue shock syndrome. Further, unusual dengue manifestation more frequently observed within the last decade. ${ }^{4}$ Definite diagnosis of dengue infection is therefore hardly determined solely on the basis of clinical symptoms and signs, especially whenever other arbovirus cocirculate. Laboratory confirmation is require in majority of cases. ${ }^{2,5}$ Since IgM-antidengue antibodies has been reported as one among other immune responses that appear earlier in

Department of Microbiology, Faculty of Medicine, University of Indonesia, Jakarta, Indonesia the course of the diseases, short lasting and relatively specific for dengue, ${ }^{2,5}$ capturing IgM-anti-dengue in human sera for rapid and simple diagnosis is attracting to be elaborated.

In previous report, we have described that a dot immunoassay employing biotinylated-dengue (BDIA) can be used to detect IgM-antidengue antibodies. ${ }^{6,7,8}$ Here we report a comparative study on sensitivity of BDIA and commercially available dot immunoassay (CDIA) for diagnosis of dengue infection.

\section{MATERIALS AND METHODS}

\section{Patient recruitment}

Serum samples were obtained from patients clinically diagnosed as dengue haemorhagic fever and mild undifferentiated fever. Haemagglutination inhibition (HI) test, according to Clarke and Casals method, ${ }^{9}$ employing 4-8 HAU/0.025 ml of four type dengue antigens on a microtiter plate was used to confirm clinical diagnosis of the patients. Classification of 
immune response to dengue was done according to W.H.O criteria. ${ }^{2}$

\section{Biotinylation of dengue viruses}

Laboratory adapted dengue 1,2,3 and 4 virus infected C6/36 monolayer cell culture fluid was clarified from cellular debris by low speed centrifugation. Viruses in supernatant fluid were precipitated by polyethylene glycol and centrifuged at $10,000 \mathrm{rpm}$ for 30 minutes. The virus in the pellet was biotinylated by biotinyl-eamidocaproic acid $\mathrm{N}$-hydroxy succinimide ester as previously described. $^{6}$

\section{Dot immunoassay employing biotinylated dengue virus (BDIA)}

BDIA was performed as previously described. ${ }^{7}$ Briefly, anti human IgM was blotted on a piece of nitrocellulose paper, blocked with $2 \%$ skim milk and air dried. Diluted test serum was then applied to the paper and incubated at room temperature for two hours. Reactions of $\operatorname{IgM}$ and biotinylated dengue as well as biotinylated dengue and horse-radish peroxidase-labelled streptavidin were done at room temperature for one hour each. Finally, 5chloronaphthol substrate was added for color development. After 30 minutes incubation at room temperature, the result of the test was observed by naked eyes and expressed as positive when a purplesolid color appeared on the blot and negative when the blot was colorless. The test was done in duplicate. Quality control of the test was done using reactive and non reactive control sera from dengue blot kit. When the result of the controls were inappropriate, the test was repeated.

\section{IgM anti-dengue detection by commercially available dot immunoassay (CDIA)}

In parallel to BDIA, rapid procedure assay of commercially available Dengue Blot IgM (Diagnostic Biotechnology Ltd) was performed. Briefly, test serum was reacted to anti $\mu$ chain of human IgM which has been blotted on a membrane for one hour at $37^{\circ} \mathrm{C}$. Following that, dengue antigens were added and incubated for two hours at $37^{\circ} \mathrm{C}$; group-reactive monoclonal antibodies to dengue antigens were added for two hours at $37^{\circ} \mathrm{C}$; working conjugate solution was added for one hour at $37^{\circ} \mathrm{C}$ and working substrate solution was added for 30 minutes at $37^{\circ} \mathrm{C}$. Result of the tests were compared with naked eyes with non reactive control and expressed as positive when a purple-ring type blot appeared on the blot and negative when the blot was colorless.

\section{Data analysis}

Sensitivity, specificity and positive value of BDIA and CDIA as compared to H.I. were calculated as described previously. ${ }^{10}$ Brief description is shown below :

\begin{tabular}{ccc}
\hline \multirow{2}{*}{ BDIA or CDIA } & \multicolumn{2}{c}{ H.I } \\
\cline { 2 - 3 } & + & - \\
\hline+ & $\mathrm{a}$ & $\mathrm{b}$ \\
- & $\mathrm{c}$ & $\mathrm{d}$ \\
\hline
\end{tabular}

Sensitivity is a divided by $(a+c)$, specificity is d divided by $(b+d)$, positive predictive value is a divided by $(a+b)$.

The difference between BDIA and CDIA is analyzed by Mc Nemar test applying Yates correction and one degree of freedom. ${ }^{\text {II }}$ When $\mathrm{p}$ value is less than 0.05 , the BDIA and CDIA is scored as significantly different.

\section{RESULTS}

\section{Validity of BDIA for diagnosis of dengue infection}

Comparison of H.I test and BDIA to confirm dengue infection on acute and convalescent sera are shown on Table 1 and Table 2 . On acute sera, 80 cases could be confirmed as dengue infection cases by BDIA and 24 cases could not be confirmed. In these cases, BDIA had a sensitivity of $76.9 \%$, specificity of $88.1 \%$ and positive predictive value of $94.1 \%$. On convalescent sera, 96 cases could be confirmed as dengue infection cases by BDIA and only 8 cases could not be confirmed. BDIA had a sensitivity of $92.3 \%$, specificity of $88.1 \%$ and positive predictive value of $95.0 \%$ on convalescent sera. Compared to blot of acute sera, most of the blot of convalescent sera revealed darker color. Typical example of the result is shown on Figure 1.

Table 1. Comparison between H.I test and BDIA on acute sera

\begin{tabular}{ccc}
\hline \multirow{2}{*}{ H.I. } & \multicolumn{2}{c}{ DIA employing biotinylated dengue } \\
\cline { 2 - 3 } & $(+)$ & $(-)$ \\
\hline$(+)$ & 80 & 24 \\
$(-)$ & 5 & 37 \\
\hline
\end{tabular}


Table 2. Comparison between H.I test and BDIA on convalescent sera

\begin{tabular}{ccc}
\hline \multirow{2}{*}{ H.I. } & \multicolumn{2}{c}{ DIA employing biotinylated dengue } \\
\cline { 2 - 3 } & $(+)$ & $(-)$ \\
\hline$(+)$ & 96 & 8 \\
$(-)$ & 5 & 37 \\
\hline
\end{tabular}

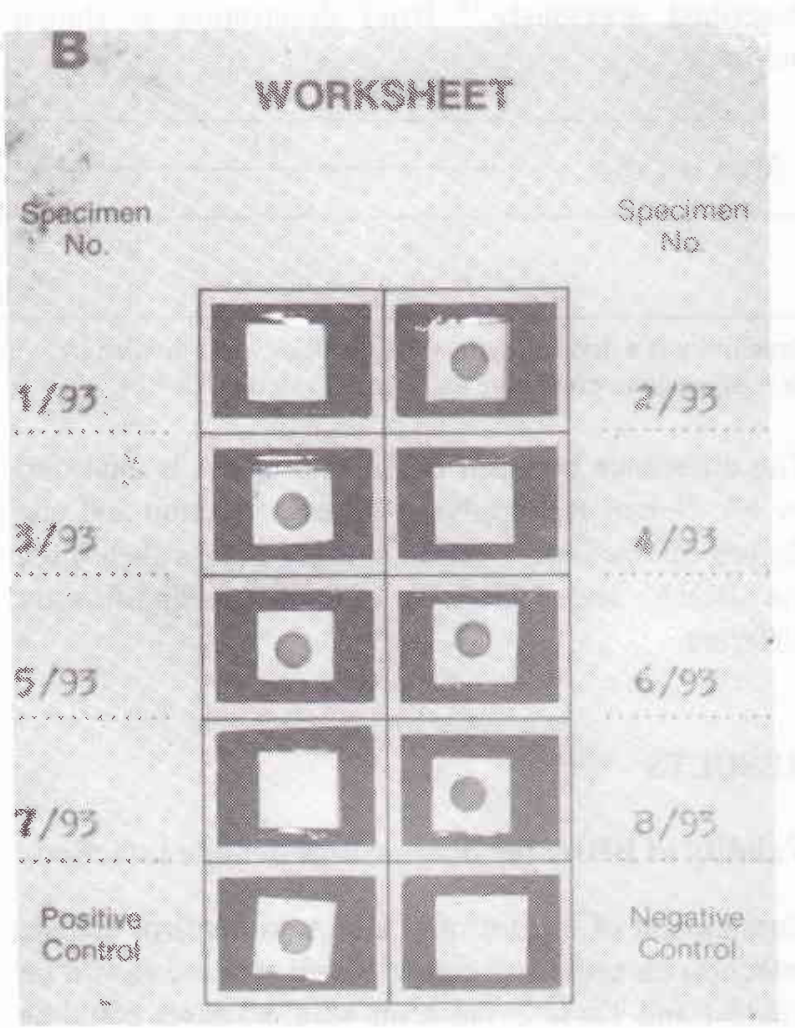

Figure 1. Typical results of BDIA

Patients and controls sera were subjected to BDIA. Positive result is shown as solid dots. Negative result is shown as colorless dots.

Validity of CDIA for diagnosis of dengue infection Comparison between H.I test and CDIA results are shown on Table 3 and Table 4. On acute sera, 44 cases could be confirmed as dengue infection cases by CDIA and 60 cases could not be confirmed. In these cases, CDIA had a sensitivity of $42.3 \%$, specificity of $92.8 \%$ and positive predictive value of $93.6 \%$. On convalescent sera, 74 cases could be confirmed as dengue infection cases by CDIA and 30 cases could not be confirmed. CDIA on convalescent sera had a sensitivity of $71.1 \%$, specificity of $90.5 \%$ and positive predictive value of $94.9 \%$.
Table 3. Comparison between H.I test and CDIA on acute sera

\begin{tabular}{ccc}
\hline \multirow{2}{*}{ H.I. } & \multicolumn{2}{c}{ CDIA } \\
\cline { 2 - 3 } & $(+)$ & $(-)$ \\
\hline$(+)$ & 44 & 60 \\
$(-)$ & 3 & 39 \\
\hline
\end{tabular}

Table 4. Comparison between H.I test and CDIA on convalescent sera

\begin{tabular}{ccc}
\hline H.I. & \multicolumn{2}{c}{ CDIA } \\
\cline { 2 - 3 } & $(+)$ & $(-)$ \\
\hline$(+)$ & 74 & 30 \\
$(-)$ & 4 & 38 \\
\hline
\end{tabular}

Comparison between BDIA and CDIA for diagnosis of dengue infection on acute sera

Table 5 and table 6 show results of BDIA and CDIA for diagnosis of primary and secondary dengue infection on acute sera. $56.5 \%$ primary dengue infection cases could be confirmed by conducting BDIA on acute sera while those by CDIA is $8.7 \%$ cases. For secondary dengue infection, BDIA was able to confirm $82.7 \%$ cases while CDIA only $51.8 \%$ cases. Result of Mc Nemar test indicated that $p$ value for primary and secondary infection are less than 0.001 and less than 0.001 , respectively.

Table 5. Comparison between BDIA and CDIA for diagnosis of primary dengue on acute sera

\begin{tabular}{cccc}
\hline \multirow{2}{*}{ BDIA } & \multicolumn{2}{c}{ CDIA } & Total cases \\
\cline { 2 - 3 }+ & + & - & 67 \\
\hline- & 40 & 27 & 14 \\
\hline Total cases & 2 & 12 & 81 \\
\hline
\end{tabular}

Comparison between BDIA and CDIA for diagnosis of dengue infection on convalescent sera

Comparative results of BDIA and CDIA on convalescent sera showed that BDIA was able to confirm the infection in $82.6 \%$ primary dengue cases while those of CDIA in $52.2 \%$ primary dengue cases. Positive results of BDIA and CDIA on convalescent sera of secondary dengue infection were $95.1 \%$ and $76.5 \%$, respectively. Result of Mc Nemar test indicated that $p$ value for primary and secondary infection are less than 0.05 and less than 0.001 , respectively. Details are shown in table 7 and table 8 . 
Table 7. Comparison between BDIA and CDIA for diagnosis of primary dengue on convalescent sera

\begin{tabular}{cccc}
\hline \multirow{2}{*}{ BDIA } & \multicolumn{2}{c}{ CDIA } & Total cases \\
\cline { 2 - 3 } & + & - & \\
\hline+ & 12 & 7 & 19 \\
- & 0 & 4 & 4 \\
\hline Total cases & 12 & 11 & 23 \\
\hline
\end{tabular}

Table 8. Comparison between BDIA and CDIA for diagnosis of secondary dengue on convalescent sera

\begin{tabular}{cccc}
\hline \multirow{2}{*}{ BDIA } & \multicolumn{2}{c}{ CDIA } & Total cases \\
\cline { 2 - 3 } & + & - & \\
\hline+ & 61 & 16 & 77 \\
- & 1 & 3 & 4 \\
\hline Total cases & 62 & 19 & 81 \\
\hline
\end{tabular}

\section{DISCUSSION}

Several laboratory approaches to confirm dengue infection in suspected cases have been developed. 2,9,12,13,14,15 Polymerase chain reaction and virus isolation are among the most accurate techniques ${ }^{2}$ in term that a positive result of the test is indisputable. Those techniques, however, is not suitable to be routinely used in developing countries where laboratory facilities are relatively insufficient. Therefore, W.H.O recommended HI test as a routine test for diagnosis of dengue infections. Unfortunately, interpretation of $\mathrm{HI}$ test require a pair of sera taken at least a week apart. Therefore, though the HI test is practical in term of the methodology, result of the test can not be drawn soon providing that the test result can not be used as a guidance for case management and prompt disease control.

Previously, we have developed a new format of DIA for detection of IgM-anti-dengue antibodies. ${ }^{7}$ Here, we report a comparative study on sensitivity of BDIA and CDIA for diagnosis of dengue infection. The results indicate that on acute sera number of primary dengue infected cases diagnosed by BDIA is at least six times more than those diagnosed by CDIA. In case of secondary infection, the proportion of cases diagnosed by BDIA compared to CDIA is almost two times, indicating that BDIA is superior to CDIA for determination of dengue infection on acute sera. On convalescent sera, BDIA also show superiority compared to CDIA though the differences is not as high as on acute sera. Indication that BDIA is superior to CDIA was confirmed by Mc Nemar test.
Overall results indicate that sensitivity of BDIA for acute sera is almost two times compared to CDIA. On convalescent sera, the sensitivity of BDIA is higher than CDIA, though not as high as on acute sera. Contrastly, the specificity of both techniques, BDIA and CDIA, are very high and the differences of specificity between BDIA and CDIA is not significant compared to those of sensitivity.

\section{CONCLUSION}

BDIA has a high sensitivity and specificity for diagnosis of dengue infection, especially on convalescent sera. Comparative assessment with CDIA indicate that BDIA is superior to CDIA. Overall results indicate that BDIA could be used as a simple and sensitive routine laboratory diagnostic for dengue infection. However, further clarification involving larger sample is required.

\section{REFERENCES}

1. Gubler DJ. Resurgence of vector-borne diseases as a global health problem. Emerg Infect Dis 1998; 4:442-50.

2. World Health Organization. Dengue Haemorhagic. Fever. Diagnosis, Treatment, Prevention and Control. WHO Geneva 1997, p. 1-68.

3. Greenberg RN, Feinberg JE and Pomeroy C. The Hot Zone 1997: Emerging Infectious Diseases. Emerg Infect Dis 1998; 4:135-7.

4. Lam SK. Emerging infectious disease- South East Asia. Emerg Infect Dis 1998; 4:145-7.

5. Suvatte V. Immunological aspects of dengue haemorrhagic fever studies in Thailand. South East Asia J Trop Med Publ Health 1987; 18:312-5.

6. Agus S, Tallei T, Betty E, Amin S and Pratiwi S. Biotinlabeled Dengue Virus for Detection of IgM anti Dengue Antibodies. Indon J Clin Microb 1995; 7:25-30.

7. Agus S, Betty E, Tjahjani MS, Amin S and Pratiwi S. Development of Dot Enzyme Immunoassay for Detection of IgM antidengue. Indon J Publ Health 1996; 3:208-14.

8. Agus S, Betty E, Fera I, Mardiastuti, Tjahjani $M$ and Pratiwi S. Semiquantitative dot immunoassay for detection of IgM anti-dengue antibodies in human sera. 1999. Submitted for publication.

9. Clarke DH and Casals J. Technique for Haemaglutination. and Haemaglutination Inhibition with Arthropod-bome Viruses. Am J Trop Med Hyg 1958; 7:561-73.

10. Illstrup DM. Statistical Method in Microbiology. Clin Microb Rev 1990; 3:219-26.

11. Zar JH. Biostatistical analysis. Prentice Hall Inc. 1984. p. 156-8.

12. Cardosa MJ and Tio PH. Dot Enzyme Immunoassay: An Alternative Diagnostic aid for Dengue and Dengue Haemorhagic Fever. Bull WHO 1991; 121:741-5. 
13. Henchal EA and Putnak JR. The dengue viruses. Clin Microb Rev 1990; 3:376-96.

14. Lam SK, Devi S and Pang T. Detection of Specific IgM in Dengue Infection. South East Asia J Trop Med Publ Health $1987 ; 18: 532-8$.
15. Lanciotti RS, Calisher CH, Gubler DJ, Chang GJ and Vorndam AV. Rapid Detection and Typing of Dengue Viruses from Clinical Samples by Reverse-Transcriptase Polymerase Chain Reaction. J Clin Microb 1992; 30:54551. 